\title{
Understanding the socio-institutional context to support adaptation for future water security in forest landscapes
}

\author{
Tahia Devisscher $^{1}$, Raffaele Vignola ${ }^{2,3}$, Monica Coll Besa ${ }^{1}$, Romy Cronenbold $^{4}$, Nelson Pacheco $^{4}$, Ralf Schillinger $^{5}$, Virginia Canedi $^{5}$, \\ Claudio Sandoval $^{6,7}$, Diego Gonzalez $^{8}$ and Grégoire Leclerc ${ }^{2,9}$
}

\begin{abstract}
During the first half of the 21st century, socioeconomic development is expected to contribute faster and to a greater extent to global water stress than climate change. Consequently, we aimed to identify conditions that can facilitate local adaptation planning for future water security, accounting for the socio-institutional context, developmental needs, and interests affecting water use and management. Our study focused on three forest landscapes in Latin America where water stress was identified as a current concern potentially leading to future social conflict if not addressed. In the three sites, we adopted a participatory approach to implement a systematic diagnostic framework for the analysis of socio-institutional barriers and opportunities influencing local adaptation decision making. This novel application enabled science-society engagement in which civil society organizations were coleading the research. The field methods we used involved participatory social network mapping, semistructured interviews, and validation workshops. Our study generated insights into several interventions that could help overcome barriers affecting the adaptation decision-making process, particularly in the diagnosis and early planning phases. Points of intervention included fostering local participation and dialogue to facilitate coproduction of knowledge, and strengthening the role of key central actors in the water governance networks. These key actors are currently bridging multiple interests, information sources, and governance levels, and thus, they could become agents of change that facilitate local adaptation processes. Working jointly with civil society to frame the research proved effective to increase awareness about water issues, which related not only to the technological, economic, and political aspects of water, but also to organizational processes. The involvement of civil society created genuine interest in building further capacity for climate adaptation and water security.
\end{abstract}

Key Words: climate change adaptation; knowledge coproduction; Latin America; local development; science and society interface; water security

\section{INTRODUCTION}

It is increasingly clear that global water stress in the first half of the 21 st century will be more affected by changes in water demand due to population and socioeconomic growth than by climate change (Vörösmarty et al. 2000, Shiklomanov and Rodda 2003, Magrin et al. 2014). Both the level of water stress and its rate of change will determine the capacity of society and nature to adapt (Alcamo et al. 2007, Döll 2009).

Since the 1990s, several Latin American countries have undertaken legal reforms to address future water stress. New policies have been developed in the water sector to reduce vulnerability to climate variability while promoting social participation (Tortajada 1999, Hantke Domas 2011, Jiménez Cisneros et al. 2014). Although practice is lagging far behind policy formulation, these ongoing reforms have helped increase general awareness among the public about the current and future state of water resources (Hantke Domas 2011). However, to achieve long-term adaptation for future water security, substantial work remains to be done to align these emerging regulatory policies and new strategies with on-the-ground implementation and local lived realities. Our study attempts to address this gap by examining the local socio-institutional dynamics that ultimately shape, facilitate, or hinder the implementation of adaptation policies and strategies relevant to water security.
To achieve our stated objective, we combined two methodological approaches in an innovative way. First, we adapted the diagnostic framework developed by Moser and Ekstrom (2010) to conduct a systematic analysis of the socio-institutional barriers and opportunities influencing the adaptation decision making for water security. Second, we applied the framework through a participatory approach, engaging civil society organizations to frame the research questions and conduct the analysis.

Using the indicated approaches, we expected to generate insights into ways that can help take better advantage of existing institutional and social opportunities to overcome barriers hindering adaptation planning for water security. While we acknowledge that the results of our study are context specific, we tried as much as possible to build on commonalities identified across different case studies in Latin America in the hope of generating broad insights that could be relevant for the region as a whole. Three specific research questions guided the research: (1) Who are the key actors in the water governance network and how could they facilitate adaptation? (2) What barriers hinder climate adaptation decision making for future water security? (3) What opportunities and interventions could help overcome these barriers?

\section{Application of a diagnostic framework}

Moser and Ekstrom (2010) published a diagnostic framework to systematize the identification of barriers that impede the

${ }^{1}$ Stockholm Environment Institute, ${ }^{2}$ Tropical Agricultural Research and Higher Education Center, ${ }^{3}$ Institute for Environment, Resources and Sustainability, University of British Columbia, ${ }^{4}$ Fundación para la Conservación del Bosque Chiquitano, ${ }^{5}$ Asociación Bosque Modelo Jujuy, ${ }^{6}$ Corporación de Desarrollo Privado SEPADE, ${ }^{7}$ Gobernación Provincial Malleco, ${ }^{8} \mathrm{PwC}$ Chile, ${ }^{9}$ French Agricultural Research Centre for International Development 
adaptation decision-making process. The framework also helps identify opportunities that can be created to allocate resources better and strategically design processes to overcome these barriers. Rather than proposing a normative approach, the framework is descriptive in detecting barriers at different phases of an idealized adaptation process. Moser and Ekstrom (2010:2) refer to the phases as "common phases of a rational decisionmaking process, including understanding the problem, planning adaptation actions, and managing the implementation of the selected option(s)." Although Moser and Ekstrom (2010) recognize that decision-making processes are typically less linear in practice, they propose these three phases for convenience to be more systematic.

In the framework, barriers are described as impediments that can stop, delay, or divert the adaptation process. In the first phase of understanding the problem, barriers relate to how the problem is perceived, if it is perceived at all. Moser and Ekstrom (2010) argue that if actors do not reach a minimum threshold of concern (i.e., perceive a signal over the detected issue) and see a clear need for a sensible response, then the adaptation process will not enter the next stage. Thus, barriers may include processes that may impede progress from one phase to another or may result in unintended consequences in the long term. In the planning phase, barriers hinder or delay the development, assessment, and selection of adaptation options. Barriers in the last phase tend to obstruct effective management or implementation.

The framework further suggests categorizing barriers according to their spatial and temporal origins. This categorization helps locate possible "points of intervention" to overcome the barriers. The temporal dimension refers to contemporary vs. legacy barriers, whereas the spatial dimension is relative to the locations of the actor(s) formulating the adaptation response and can be understood as proximate vs. remote barriers. In our study, we identified barriers considering the temporal dimension, but did not include the location of origin. It was difficult to make a spatial categorization given the interconnectedness of adaptation decision-making process and formulation of response across scales.

By understanding the nature of the barriers using the diagnostic framework, we intended to generate insights about key points of intervention that could circumvent, remove, or lower the barriers. According to Moser and Ekstrom (2010), identifying these points of intervention is often the main focus of the initial adaptation effort, even if it does not necessarily lead to a "successful" outcome. This process is considered highly context sensitive, which is why a systematic diagnostic framework may be more useful than a prescriptive list of one-size-fits-all necessary conditions, capacities, or steps to overcome barriers.

We applied the diagnostic framework to look specifically at social and institutional barriers and opportunities. The social dimension included the actors and their interactions in the water governance networks, and the potential agency (e.g., "agents of change") that could play a key role in facilitating adaptation. The focus on the social dimension is supported by the recognition that system-level change is enacted through the interactions of many actors and the resources they mobilize, whether these are intended or emergent features of the adaptation process. To some extent, this dimension also includes looking at the role of power, which can be broadly understood as the actual or perceived influence over others, over agendas, and over perspectives using either actorspecific resources to fulfill self-interests, or building on the capacity of a social system to mobilize resources collectively to realize common goals (Avelino and Rotmans 2009).

The institutional dimension refers to the norms and procedures governing the relationships and interdependencies among actors and resources. Ostrom (2005) defines institutions as the prescriptions that humans use to organize all forms of repetitive and structured interactions, including those within families, markets, firms, etc. Institutions we considered included culture, norms, laws, regulations, decision spaces, and routines relevant to the adaptation decision-making process for future water security.

\section{Adopting a participatory approach}

To apply the diagnostic framework, we adopted a participatory approach working at the science-society interface. This approach was envisaged as an alternative to the linear model postulated for the science-policy interface (Bradshaw and Borchers 2000, Pielke 2007), where science is perceived as a neutral provider of objective knowledge that is then transmitted to the decision-making domain in charge of developing policy (Nutley et al. 2007, Van den Hove 2007). This linear model has been criticized for falling short in generating effective dialogue and useful information and being different from actual science-policy processes, which are far from linear and are rather complex, iterative, and often selective in the information used (Vogel et al. 2007).

Recently, Young et al. (2014) investigated different ways to improve the function of the science-policy interface. They recommended framing research and policy jointly (i.e., changing the way problems are currently framed and agreed upon) and promoting inter- and transdisciplinary research working in multidomain groups that include both scientists from different disciplines and actors from various fields and sectors. Collaborative work that incorporates such processes has demonstrated great potential to integrate not only different academic disciplines but also the perspectives and forms of knowledge of different groups of people concerned (Van den Hove 2006, Leach et al. 2010, Young et al. 2013).

Building on these previous recommendations, we adopted an approach that allowed framing the research questions and conducting the analysis jointly with civil society organizations (CSOs). The CSOs were based in the study sites and helped coordinate the research efforts and create multidomain groups involving a range of local actors, including actors from the private and public sectors. In each site, these groups studied the socioinstitutional processes that influence the integration of climate considerations into water management decisions.

We refer to the joint work conducted in this study as a process of coconstruction. From the very beginning, we recognized that this process of coconstruction needed to be iterative, flexible, and inclusive to facilitate knowledge exchange and learning among the actors concerned. Ultimately, we expected that by building on the perspectives of multiple actors in the study sites, we would generate findings that are relevant and useful to inform local adaptation decisions (Cash et al. 2003, Lemos et al. 2012). 


\section{METHODS}

\section{Study sites selection and description}

The collaborative research was conducted in three contrasting Latin American model forests, namely the Jujuy Model Forest (JMF) in Argentina, the Chiquitano Model Forest (CMF) in Bolivia, and the Araucarias del Alto Malleco Model Forest (AAMMF) in Chile (Fig. 1). Globally, model forests are models of governance based on an approach that combines the social, cultural, and economic interests of local people with the longterm sustainability and conservation of large forest landscapes with clearly defined boundaries (IMFN 2011).

Fig. 1. Map showing study sites located in the Chiquitano Model Forest (CMF), Municipality of Concepción, Bolivia; the Jujuy Model Forest (JMF), Province of Jujuy, Argentina; and the Araucarias del Alto Malleco Model Forest (AAMMF), Communes of Lonquimay and Curacautín, Chile. The map also shows the administrative capital cities of the three Latin American countries, namely La Paz, Bolivia; Buenos Aires, Argentina; and Santiago, Chile. Map was visualized using 2016 Google Imagery, NASA, TerraMetrics.

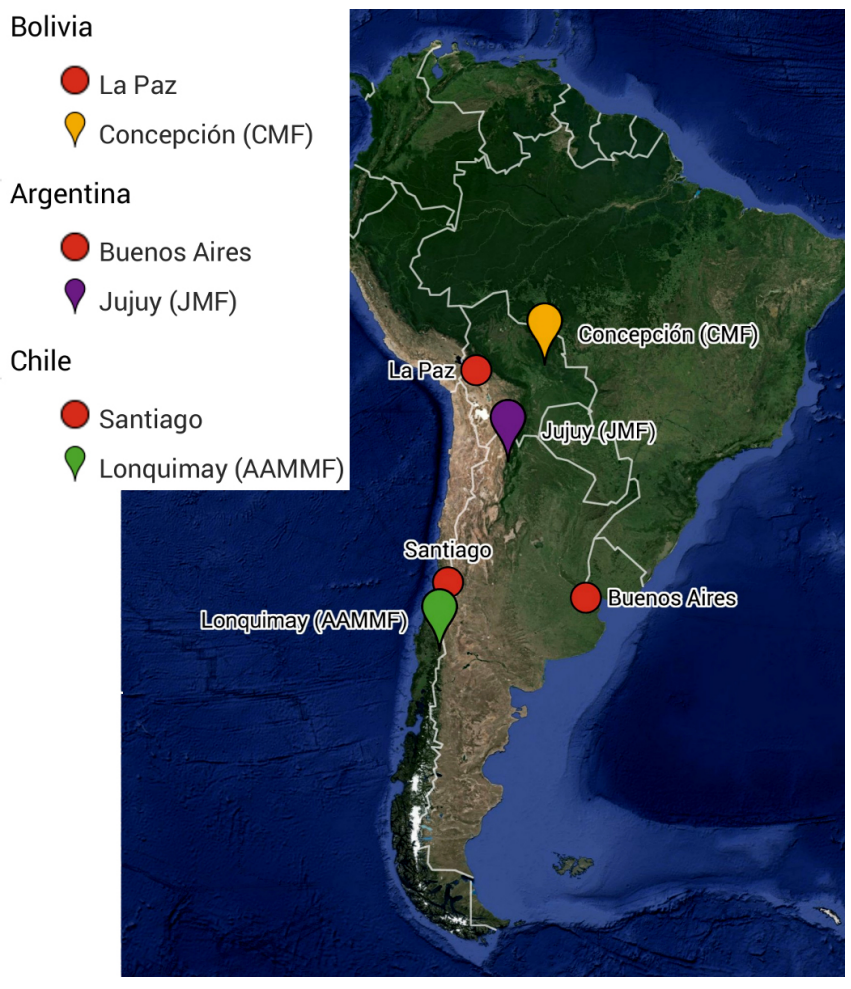

The model forest concept was developed by the Government of Canada in the early 1990s and introduced in that country as an alternative strategy to prevent and transform conflicts between forest loggers and communities living in forested areas over the management and use of forest resources (http://www.imfn.net/ international-model-forest-network). The concept proved promising; people came to the table to discuss issues they faced and possible solutions related to logging practices, biodiversity conservation, and economic stability. Since then, the network of model forests has expanded globally, with $>60$ model forests organized in six regional networks covering 84 million ha in 31 countries. In Latin America, the first model forest was founded in 1996. By the time of our study, 30 model forests had been established in the region, covering $>31$ million ha over 15 countries (Ibero-American Model Forest Network: http://www. bosquesmodelo.net/en/quienes-somos/).

All model forests are managed by multiactor platforms (model forest boards), which are interconnected through a global network (Elbakidze et al. 2010). In the three study sites, the model forest boards are facilitated by local CSOs. These local CSOs were engaged in the process of coconstruction facilitated by our study. The CSOs worked jointly with a team of scientists to coordinate efforts and engage a range of local actors in the study. To avoid confusion with terminology, we use the term model forest when referring to the spatial area of the landscape, model forest board when referring to the platform of actors comanaging the landscape, and model forest CSO when referring to the local CSO coordinating the platform. In the JMF, the CSO facilitating the board and coleading this research was the Asociación Bosque Modelo Jujuy. In the CMF, the CSO was the Fundación para la Conservación del Bosque Chiquitano (FCBC). In the AAMMF, the CSO was the Servicio Evangélico Para el Desarrollo (SEPADE).

The three case studies were selected for the following reasons. First, they were landscapes formally recognized as model forests with clear spatial boundaries and commitment to participatory conservation based on multiactor platform dialogue, which offered a space to discuss issues of common concern such as water security and climate change. Second, water stress was identified as one of the main causes of current concern that could lead to future conflict if not addressed, which called for urgent action. Third, the local CSOs facilitating the model forest boards had been working in the sites for approximately one decade; thus, coleading this research with them provided the opportunity to build on their accumulated knowledge about the context, their established networks, and their commitment to sustainability in the model forests.

Given the extensive area of the model forests, the local CSOs suggested focusing on a smaller pilot area within the model forest to implement the joint research. The pilot area was characteristic of the broader landscape, so that findings would be relevant to an appropriate extent to the model forest as a whole. We decided that water basins would be appropriate pilot areas because of the focus on water resources. In the JMF, the pilot area was the Pericos-Manantiales basin $\left(1500 \mathrm{~km}^{2}\right)$, located in the Province of Jujuy. The total population in the basin was approximately 100,000 , with $80 \%$ urban. We focused particularly on the middle area of the basin, which is locally known as the Area de los diques $y$ perilagos (Area of the dams and its surroundings). This area is densely populated and is characterized by a dynamic economy based on its irrigated agricultural production, especially tobacco. The Area de los diques y perilagos is considered a tourist destination, with urban housing, rural dwellers, forests, and farms surrounding the two existing dams in the area.

The pilot area in the CMF was the Zapocó River basin (1349 $\mathrm{km}^{2}$ ), located in the Municipality of Concepción. The Zapocó dam is located in the middle area of this basin. Approximately 19,000 people lived in the basin at the time of our study, of which 
approximately $20 \%$ were urban. Most of the Zapocó basin is covered by forests and cultivated pastures for cattle, although there is also agriculture in the indigenous communities. The main economic activities are livestock production, subsistence agriculture, and commercial crop farming. Logging and traditional use of forests for nontimber forest products are also important economic activities.

In the AAMMF, the CSO decided to work in two basins, namely the Bío Bío River basin $\left(24,264 \mathrm{~km}^{2}\right)$ and the Cautín River basin $\left(12,763 \mathrm{~km}^{2}\right)$, located in the communes of Lonquimay and Curacautín, respectively. Although this demanded additional work, the CSO indicated this was necessary to address the needs of the two communes that make up the AAMMF. At the time of the study, approximately 27,000 people lived in the upper parts of the Bío Bío $\left(3914 \mathrm{~km}^{2}\right)$ and Cautín $\left(1664 \mathrm{~km}^{2}\right)$ basins. Of this total, approximately $60 \%$ lived in Curacautín, where more than half of the population is urban. In Lonquimay, almost half of the population is indigenous Mapuche-Pehuenche. The main economic activities are commercial crop farming, cattle ranching, and forestry, including management of tree plantations.

\section{Data collection}

The methods used to collect field data in the model forest pilot areas were designed, adapted, and implemented with the local CSOs between August 2012 and April 2013. The methods involved social network mapping (SNM), semistructured interviews, and validation workshops. We used SNM to tackle the first research question and identify key actors in the water governance networks that could potentially facilitate adaptation planning for water security. The semistructured interviews were combined with the SNM to address the second and third research questions, i.e., to identify barriers that hinder climate adaptation decision making, and points of intervention that could help overcome these barriers. The workshops were conducted at the end of the fieldwork with the intention to feed results back to participants that took part in the research, discuss the findings, and validate and complement the information we gathered.

\section{Social network mapping}

The governance of natural ecosystems has been studied through the analysis of social network structure and function (Crona and Bodin 2010, Crona and Hubacek 2010, Newig et al. 2010, Sandström and Rova 2010, Stein et al. 2011, Vignola et al. 2013). Broadly speaking, governance could be understood as a new process of governing or a new way by which society is governed, with inclusion of different non-State actors in decision making (Andrew and Goldsmith 1998, Hooghe and Marks 2003, Klijn 2008). A growing number of scholars is studying governance as self-organizing, interorganizational networks, which can be considered governing structures that help allocate resources, exercise control, and improve coordination (Rhodes 1996, Bang 2003, Olsson et al. 2004, Crona and Hubacek 2010, Newig et al. 2010). In our study, we understood water governance networks as the public, private, and civil society organizations held together through formal and informal institutions that have a direct or indirect influence on water resources management.

We used participatory SNM to gain first an understanding of the organizations and social groups that were relevant to the water governance networks. We then identified key actors in the networks based on their level of centrality. Central actors with high numbers of connections or high levels of influence in the decision-making process were considered potential agents of change with the ability to play an important role in facilitating adaptation planning in the sites.

The SNM was based on the NetMap method originally developed by Schiffer (2007), with adaptations to include the spatial dimension. Explicitly representing the spatial dimension allowed exploring interactions between different governance levels, i.e., from the local or basin level, through the landscape or subnational level, to the national level. We considered it important to analyze links across scales to scale up or replicate adaptation actions that would be implemented initially in the pilot areas but then used to inform adaptation strategies at broader scales.

The implementation of SNM was modified by each model forest CSO to fit the specific dynamics of each site. First, the method was implemented with the CSO staff, then it was adapted, and afterwards it was implemented with different local actor types, including public entities, rural communities, and representatives of the private sector. The participatory approach allowed capturing different perspectives to gain a more complete picture of the whole water governance network in each site (Schiffer and Hauck 2010).

The number of actors participating in the mapping exercise of a network varied according to the modality applied by the CSO, ranging from three to ten participants in a group. In the JMF, the CSO facilitated two SNM exercises, working first with a group of representatives of the municipal government and then with a group of representatives of the Intendencia de los Diques (public entity in charge of managing the Area de los diques y perilagos). In the AAMMF, two network maps were developed by different working groups in a workshop setting. One group involved entrepreneurs of the private sector, and the other involved farmers and nongovernmental organizations. Representatives of public institutions mapped a third network in meetings that followed the workshop. In the CMF, the CSO facilitated a workshop in which networks were developed by three different groups, namely representatives of local communities and grassroots organizations, representatives of public entities, and representatives of the private sector.

For the SNM exercise, participants in each group were first asked to identify organizations and social groups (actors) relevant to water resources in the model forest pilot area. Actors were listed either because they were directly using or benefiting from water resources in this area or because they had a role to play in the decision making for water management. The actors were then associated to specific spatial scales (i.e., their scale of action or jurisdiction). Participants then mapped two types of relationships among the actors to represent information flows (directed connections) and collaboration for water planning and management (undirected connections). Finally, the level of influence was discussed and agreed upon for each of the actors in the network. This represented the local shared perception of how much influence an actor may have on the decisions underpinning water management. Participants were asked to discuss the level of influence, ranking each actor on a scale from 0 to 3 , where 3 represented high level of influence and 0 meant little or no influence at all. The level of influence of an actor could only really be understood in relation to other actors in the whole network (Smith et al. 2005). 
Table 1. Number and type of informants interviewed in each case study site.

\begin{tabular}{|c|c|c|c|}
\hline Actor type or sector & Chiquitano Model Forest, Bolivia & Jujuy Model Forest, Argentina & $\begin{array}{l}\text { Araucarias del Alto Malleco Model Forest, } \\
\text { Chile }\end{array}$ \\
\hline $\begin{array}{l}\text { Rural communities or } \\
\text { farmers }\end{array}$ & $\begin{array}{l}20 \text { communities in the Zapocó River } \\
\text { basin }(\sim 200 \text { people })\end{array}$ & 3 farmers in the rural area & $\begin{array}{l}3 \text { Mapuche communities, } 5 \text { colono- } \\
\text { campesino communities }\end{array}$ \\
\hline $\begin{array}{l}\text { Entrepreneurs in the private } \\
\text { sector and urban } \\
\text { inhabitants }\end{array}$ & $\begin{array}{l}14 \text { informants in the urban area of } \\
\text { Concepción, } 3 \text { private cattle } \\
\text { ranchers }\end{array}$ & $\begin{array}{l}9 \text { informants in the private sector, } \\
\text { including the local media and a } \\
\text { public-private company }\end{array}$ & $\begin{array}{l}3 \text { informants in the urban area of the } \\
\text { Lonquimay and Curacautín communes }\end{array}$ \\
\hline $\begin{array}{l}\text { Representatives of the } \\
\text { public sector }\end{array}$ & $\begin{array}{l}6 \text { representatives of local public } \\
\text { entities }\end{array}$ & $\begin{array}{l}15 \text { representatives of public } \\
\text { institutions }\end{array}$ & $\begin{array}{l}3 \text { representatives of public entities in the } \\
\text { communes of Lonquimay and Curacautín, } \\
4 \text { national government officials }\end{array}$ \\
\hline Civil society organizations & $\begin{array}{l}5 \text { nongovernmental organizations } \\
\text { (including grassroots organizations) }\end{array}$ & $\begin{array}{l}2 \text { nongovernmental organizations } \\
\text { (including a research institute) }\end{array}$ & 4 civil society organizations \\
\hline
\end{tabular}

Actors' influence was differentiated between formal and informal. An actor could have one or the other or a combination of both. Formal influence was conceived as the ability to dictate or influence decisions through legal mandate, i.e., the authority in making demands upon the behavior of others through legislation or regulation enforcement (e.g., see "authority power" defined by Smith et al. 2005, Avelino and Rotmans 2009). We considered informal influence as the sum of capacities able to influence water management decisions based on the ability to control and mobilize political, human, and monetary resources through informal institutions (e.g., see "shadow spaces" defined by Pelling et al. 2008).

\section{Semistructured interviews}

We complemented the network mapping with semistructured interviews (Table 1). In each site, interviews followed a similar overall structure but there was flexibility to ask questions according to the background of each informant. The first set of questions aimed at understanding the current use of water resources in the localities and the recent changes or issues affecting the resource. The following set of questions aimed at understanding the role of different actors in the water governance network and the institutions affecting the way they interact. Questions about existing decision spaces, collaboration, and learning were included in this set of questions. A final set of questions focused on observed or perceived changes in the weather patterns and associated positive and negative impacts. Questions about coping strategies were included in this final set.

The local CSOs coordinated the identification of key informants to interview in the sites. Informants were selected based on their representativeness of a particular actor type, the years of experience working on or living in the model forest pilot areas (minimum of $5 \mathrm{yr}$, ideally $10 \mathrm{yr}$ ), and their ability to provide a general overview of the issues affecting water resources from the perspective of their sector or social group. Without the knowledge and trust already built by the CSOs in the sites, identifying key informants would have taken additional resources and time. In this respect, the CSOs' work experience and role as facilitators of multiactor platforms in the model forests helped significantly.

Most interviews were conducted face to face on an individual basis. In the case of the CMF, interviews with local indigenous communities had to be modified to allow for group interviews. Community leaders insisted that the entire community should be present during an interview to abide by traditional rules. In the AAMMF, four interviews were conducted via e-mail to national government officials. These representatives were based in the capital city, and our resources limited long-distance travel for interviews.

\section{Validation workshops}

Local actors that participated in the interviews or network mapping were invited to attend validation workshops in each site. These workshops were an opportunity to present results to the participants that helped develop them, receive their critical feedback, and reflect about the insights we gained and the gaps in the study findings. The specific objectives of these workshops were (1) to express gratitude, provide and receive feedback, and validate and build social acceptance of the results; (2) to enrich the information we generated; (3) to raise further interest in water resources and climate change; and (4) to identify a group of local actors that would engage in the planning and implementation of adaptation pilot actions.

At the workshops, preliminary results were first synthesized and presented in posters or through discussions in plenary sessions. Next, the findings were discussed in more detail in working groups following structured exercises prepared in advance. For example, in the JMF, a physical scale model of the Los Pericos-Manantiales water basin was presented and used to discuss perceptions of water issues in different locations of the basin (e.g., landslides in the upper basin, contamination of the dams in the middle basin). The group exercises were different for each site and were adapted to fit the specific context, the work style of each CSO, and the invited participants.

\section{Analysis}

To gain a qualitative understanding of the structure of the water governance networks, we first visualized them using NetDraw v2.121 software (Borgatti 2002). We then used UCInet v6.411 software (Borgatti et al. 2002) to analyze network metrics based on graph theory. More specifically, we analyzed degree centrality (Hanneman and Riddle 2005) to identify (1) central actors with many connections that could play an important role in enhancing collaboration (Bodin and Crona 2009), and (2) bridging actors that have the capacity to link different types of actors or spatial scales in the networks (Vignola et al. 2013). We also identified weak or lack of connections, which could represent possible barriers for collaboration and adaption decision making. 
The findings of the network analysis were complemented with interview data to elaborate further on the role of agency and to identify possible mechanisms that could improve interaction in the networks (Carlsson and Berkes 2005). Interviews were voicerecorded, and most responses were transcribed by the CSOs. A summary of all interview responses was developed to present at the validation workshops. Working papers with more detailed findings were produced for each site (see Appendix 1). This current study is a cross-site analysis that brings together the findings generated in each site by building on the commonalities.

For the analysis of common factors that can halt or facilitate the adaptation process, we used the three phases of adaptation decision making proposed in the diagnostic framework by Moser and Ekstrom (2010). Using the framework as a reference, we categorized these factors according to their temporal scale, recognizing situational conditions (i.e., if they were contemporary) and structural conditions (i.e., if they were a legacy of something that has taken long time to form). We envisaged points of intervention as first steps to help build adaptive capacity in the model forests, which over time can inform the development of longer term adaptation strategies. Therefore, we conceived interventions as potentially low risk, "no-regret "actions (Klein et al. 2014, Preston et al. 2015) capable of yielding social or economic benefits and clearly enhancing prevailing management strategies (Hallegatte 2009, Jiménez Cisneros et al. 2014).

\section{RESULTS}

\section{Water issues in the model forests}

Sources of drinking water varied in the model forest pilot areas. In the densely populated middle basin of the JMF pilot area, the main water source was the complex of dams La Ciénaga and Las Maderas. In the AAMMF, groundwater was the main source of urban drinking water. In the rural areas, the main sources of water were rivers, wells, and estuaries. In the rural area of the CMF, the main source of drinking water was groundwater. However, rural communities indicated that during the dry season, wells would go dry, and then they were forced to seek alternative sources. In these instances, rivers and micro dams were used as sources of drinking water. In the urban area, the Zapocó dam was the principal source of drinking water.

Although informants in the model forest pilot areas did not perceive water security issues to have reached a critical state yet, several emerging issues were identified. In the CMF and JMF, the water issues were generally associated with human activities. Logging, farming, mining, and livestock activities were related to water contamination and sometimes physical water scarcity. In the JMF, deforestation and lack of soil conservation practices were associated with high erosion levels and seasonal landslides in the upper basin. In the middle basin, social tensions started around water distribution because of an increasing demand for irrigation, tourism, domestic use, and energy generation, exacerbated by pollution of the water dam. In the CMF, the expansion of pastures was linked to sedimentation in rivers and dams. Rural communities also mentioned deficient supply systems for drinking water (e.g., pumps would need maintenance work), and one community indicated that mining activities were negatively affecting water quality in the lower basin. In the urban area, inhabitants observed that water quality in the dam was affected by livestock, water sports, and car and laundry washing, as well as inadequate disposal of solid waste and wastewater.

In the AAMMF, the problems around water related to the existing legal framework, which was gradually contributing to a situation of "legal water scarcity." In Chile, water resources are regulated by the new Water Code, which was adopted in 1981. This legal framework promoted the privatization of water resources, which became a rapidly distributed tradable good. At the time of our study, water rights for consumptive use were unavailable in the AAMMF. It was only possible to acquire nonconsumptive use rights, which were generally held by large private companies, mainly in the hydropower sector.

The general perception across sites was that social tensions around water scarcity would intensify in the future, particularly given competing trends in domestic consumption and production activities. For example, informants in the AAMMF pointed out that the establishment of a large dam in the Bío Bío River basin for hydropower production could become a potential driver of future tensions around water availability. Informants also mentioned that changes in climate may exacerbate tensions around water security. Local farmers in the CMF perceived a delay in the onset of the rainy season, more prolonged dry spells, and more intense rainfall during a shorter wet period. Prolonged dry seasons resulted in less water availability during these periods, with negative consequences for groundwater recharge, human consumption, and activities such as agriculture and livestock production. In the JMF, local farmers observed more erratic rainfall, with consequences particularly for farming activities that were not connected to irrigation systems. In the AAMMF, interviewees mentioned an increase in temperature and more frequent snowstorms.

\section{Key actors in the water governance networks}

Through the network mapping in the three sites, we found that state actors (i.e., public entities) had a dominant presence in the water governance networks. The public sector showed not only a high number of actors in the networks, but also a high number of connections. Also, public entities tended to bridge different governance levels (local, regional, and national) and actors in the private sector and civil society with distinct interests in water in the private sector and civil society. In the CMF, we found that the municipal government was perceived to play a particularly important role in the network (Fig. 2). This was also the case for the JMF, although to a lesser extent (see Fig. A2.1 in Appendix 2). Municipal governments in these two model forests exhibited high centrality with many connections, capacity to link different scales and types of actors, and a position of information brokers (i.e., actors that receive but also share information relevant to water management). In the AAMMF, the network showed multiple hierarchical connections between the national, regional, and local governments and the private sector (see Fig. A2.2 in Appendix 2).

The participants that we engaged to map the networks indicated that public entities were important actors because they had a legal mandate to oversee and enforce regulations for water resources management in the pilot areas. For this same reason, most state actors were perceived to have formal influence in the decision making. Even so, most participants admitted they did not have a 
Fig. 2. Water governance network from the perspective of representatives of local public entities in the Chiquitano Model Forest (CMF), Bolivia. The actor nodes in the network represent organizations and social groups perceived as relevant to water resources management. The $\mathrm{x}$-axis categorizes the actor nodes according to their related sector. Civil society organizations (CSOs) include nongovernmental organizations. The y-axis categorizes actor nodes by their scale of action. The local scale relates to the pilot area in the CMF, the regional scale corresponds to the model forest landscape, and the national scale represents Bolivia. Actor node size relates to in-betweenness centrality, which corresponds to the importance of the node as a bridge in the network. See Appendix 2 for water governance networks in the Jujuy Model Forest, Argentina, and the Araucarias del Alto Malleco Model Forest, Chile. See Appendix 3 for a list of the main actors and the role they play in the water governance network according to participants' perception.

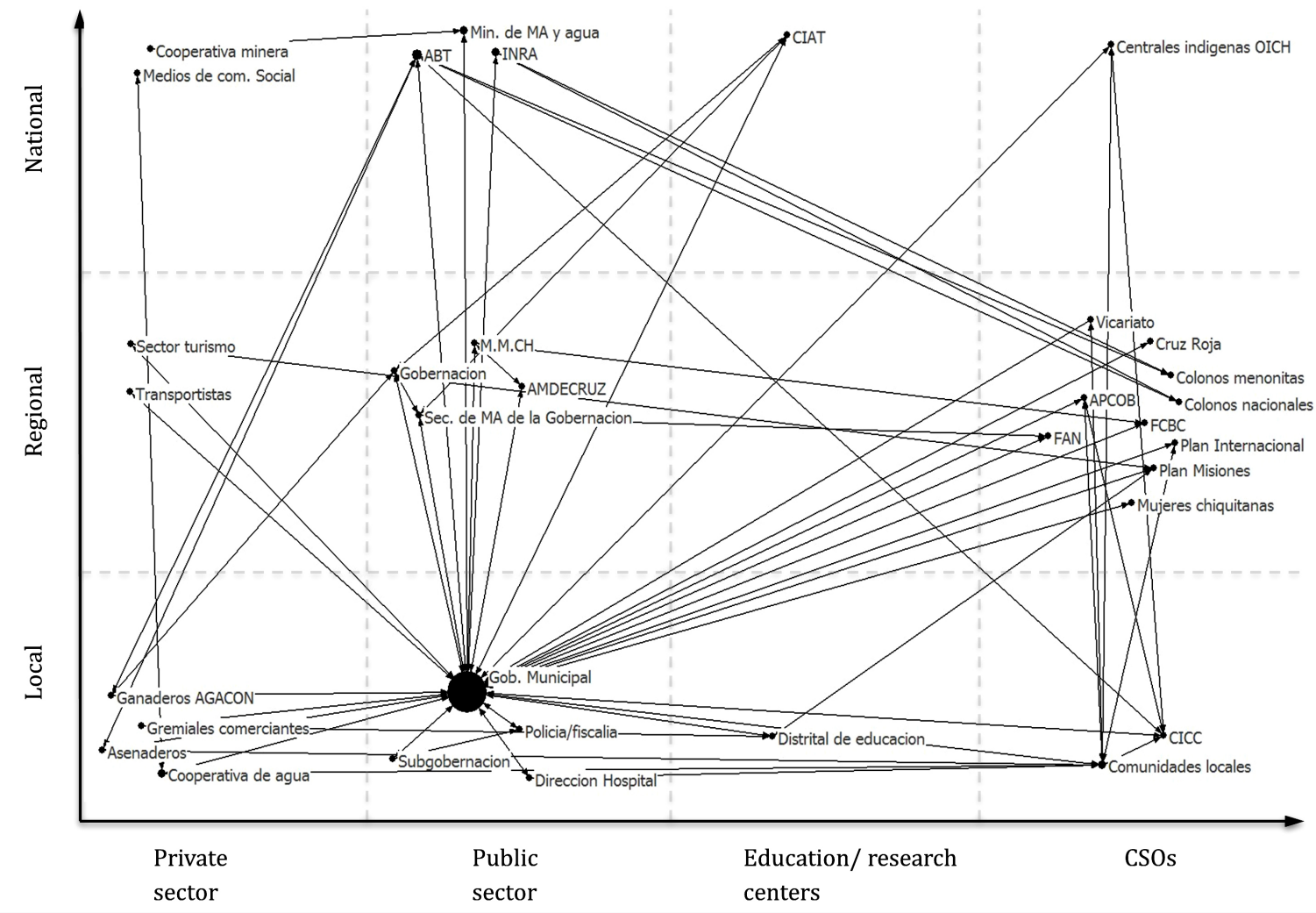

clear understanding of the roles and functions of all public entities, particularly in relation to watershed management. Indeed, participants in the three sites considered the roles of public entities to be at times overlapping and contradictory, and recognized that they knew less about the function of public entities operating at the national level. Appendix 3 provides a list of the main actors included in the networks and the role they play in the water governance network according to participants' perception.

In the three sites, the general perception was that processes led by national interests tended to overrule local plans, revealing latent tensions and power dynamics between the different governance levels. For instance, in the CMF, rural communities and local authority representatives explained that human settlements or mining activities supported by the national government would be implemented in municipal protected areas, even if the municipal government was in disagreement. These emerging conflicts were more evident in the CMF, where decentralization laws (Law N031 [Bolivia 2010], Law 482 [Bolivia 2014]) favored the development of autonomous local governments.
In particular cases, we also found that some public entities had lost legitimacy and trust among local actors. As a result, these public entities were perceived to have less formal influence in decision making, even if their specific legal mandate was to oversee water resources. For example, in the JMF, the Intendencia de los Diques in charge of managing the dams in the pilot area had lost credibility and legitimacy in recent years because its function had been hindered by instability in the leadership, high staff turnover, and political stress. Even so, participants in the JMF perceived that this entity retained a moderate level of informal influence, linked to a set of leverage mechanisms such as personal connections, cronyism, and political power.

Although public entities such as municipal governments were highly connected in the network maps, they were not considered the only actor type playing a central role in water governance. In the JMF and AAMMF validation workshops, participants highlighted the need of civil society to be more proactively involved in the planning and management of water resources. Nevertheless, representatives of the civil society in these 
workshops identified themselves as having very little influence in decision making for water resources. The only exception related to indigenous organizations in the $\mathrm{CMF}$, which were perceived to have the ability to influence management decisions through local assemblies, community annual plans, and other formal decision spaces that enable public participation under the Bolivian regulatory framework. Workshop participants also emphasized that the model forest CSOs and model forest boards could be a mechanism for civil society to be more involved in water management. Participants indicated that in the past, the model forest board in the AAMMF and the model forest CSO in the $\mathrm{CMF}$ were helpful in generating and providing information and creating a space for dialogue in the model forest landscapes.

The network maps also showed that some actors in the private sector were considered relevant for water governance (i.e., they were present in the networks). However, private sector actors generally exhibited very few connections, with the exception perhaps of the AAMMF, where the private sector had more connections in the network (Fig. A2.2 in Appendix 2). In the three sites, participants representing the private sector explained that they interact with public entities only when they are expected to respond to specific legal requirements. For instance, private enterprises in the AAMMF would interact with the Ministry of Environment to comply with environmental impact assessments.

Some actors in the private sector were perceived to have a high level of informal influence in water management decisions, mainly because of their economic and lobbying power. This was particularly the case for the Consorcio de Riego and the tobacco chamber of commerce in the JMF, the hydroelectric plants in the AAMMF, and the Cattle Rancher Federation in the CMF. At the validation workshops, participants highlighted the need to strengthen the links to influential entities in the private sector if adaptation strategies for water resources were to be inclusive of different views and, at times, conflicting interests in the landscapes.

Finally, the network maps revealed that only few education and research centers were perceived to be relevant for water governance in the sites. These actors were also weakly connected. Local universities, research organizations, and the local media (i.e., environmental journalists) seemed to be rather isolated, particularly in the CMF and JMF water governance networks.

\section{Barriers constraining adaptation planning for future water security}

The interviews generated insights into barriers that hinder adaptation decision making for future water security. Although many of these barriers were interlinked and, to a large extent, context specific, we identified common patterns that we consider could inform adaptation planning in other landscapes facing similar concerns. We provide a synthesis of the common barriers we found across the three sites (Fig. 3).

\section{Barriers in the diagnosis phase}

A common barrier affecting the diagnosis phase of the adaptation process was the limited notion of a water basin. This included misunderstandings around the spatial dimension and the biophysical characteristics that define a basin, and limited perceptions of the location of specific human activities within this space. Another barrier that complicated the diagnosis phase was that in different parts of the water basin, the perceived water issues were very distinct. In other words, there were multiple fragmented views of the water problem because these views depended on the location and social sector of the observer. For instance, in the $\mathrm{CMF}$, the problems perceived in the urban area of the middle basin related to contamination of the water dam. These problems differed from issues of water scarcity perceived in the rural areas that related more to groundwater availability. The fragmented perceptions of the water problem hampered the development of an approach that deals with these multiple views in a more integrated way at the basin level.

In the three sites, most interviewees recognized the existing interactions between forests, water, and land use. However, there was limited information and understanding about the specific mechanisms underpinning these interactions. According to interviewees, one of the main reasons was a poor or lack of connection to organizations that could produce this type of information, with technical capacity to conduct hydrological, climatic, and land-use impact studies. In some instances, as in the AAMMF, participants indicated that they knew about sources for this type of information. Still, they perceived that this information was not written or delivered in a format that was easy to understand and use to inform decisions.

Another common barrier was the uncertainty around the water stress signal. In the CMF and JMF, physical water scarcity was perceived especially in years with prolonged dry periods. Even so, interviewees attributed water scarcity mainly to human overuse than to weather conditions. In the AAMMF, the main concern around future water security was considered to be legal water scarcity. Given the regulatory disposition, the local population had started to fear losing access to water over time as large private enterprises continue accumulating water rights for cropland irrigation and hydropower projects.

\section{Barriers in the planning phase}

A common barrier hindering the adaptation planning phase was the perceived absence of a shared vision for future water security. This was particularly the case when considering all relevant stakeholders at the basin level. Indeed, different visions and interests conflicted in the model forest pilot areas. In the CMF and AAMMF, for example, influential actors of the public and private sectors focused mainly on the production potential of the landscapes. As a result, watershed conservation was considered an asset to be negotiated among production sectors linked to agriculture, hydropower generation, and livestock production. However, other actors in the CMF and AAMMF recognized the increased water demand of a growing urban population and the need to support subsistence farming, which was the main activity in indigenous communities.

Adaptation planning for water resources was also hindered by insufficient capacity, even when local participation was encouraged. In the CMF, the existing legal framework supported local participation by providing a structured process to engage local communities in development planning. Despite communities having the opportunity to plan for their water resources, we noticed that water was not prioritized or even considered in local development plans. Instead, projects to improve accessibility to drinking water in rural communities were initiated by nongovernmental organizations or the national 
Fig. 3. Categorization of the main barriers to adaptation decision making for water security in the three model forests. The text highlights common barriers among the study sites. The $\mathrm{x}$-axis organizes the barriers in terms of their relevance to the formal phases of adaptation decision making. The y-axis separates situational (contemporary) barriers from structural (legacy) barriers.

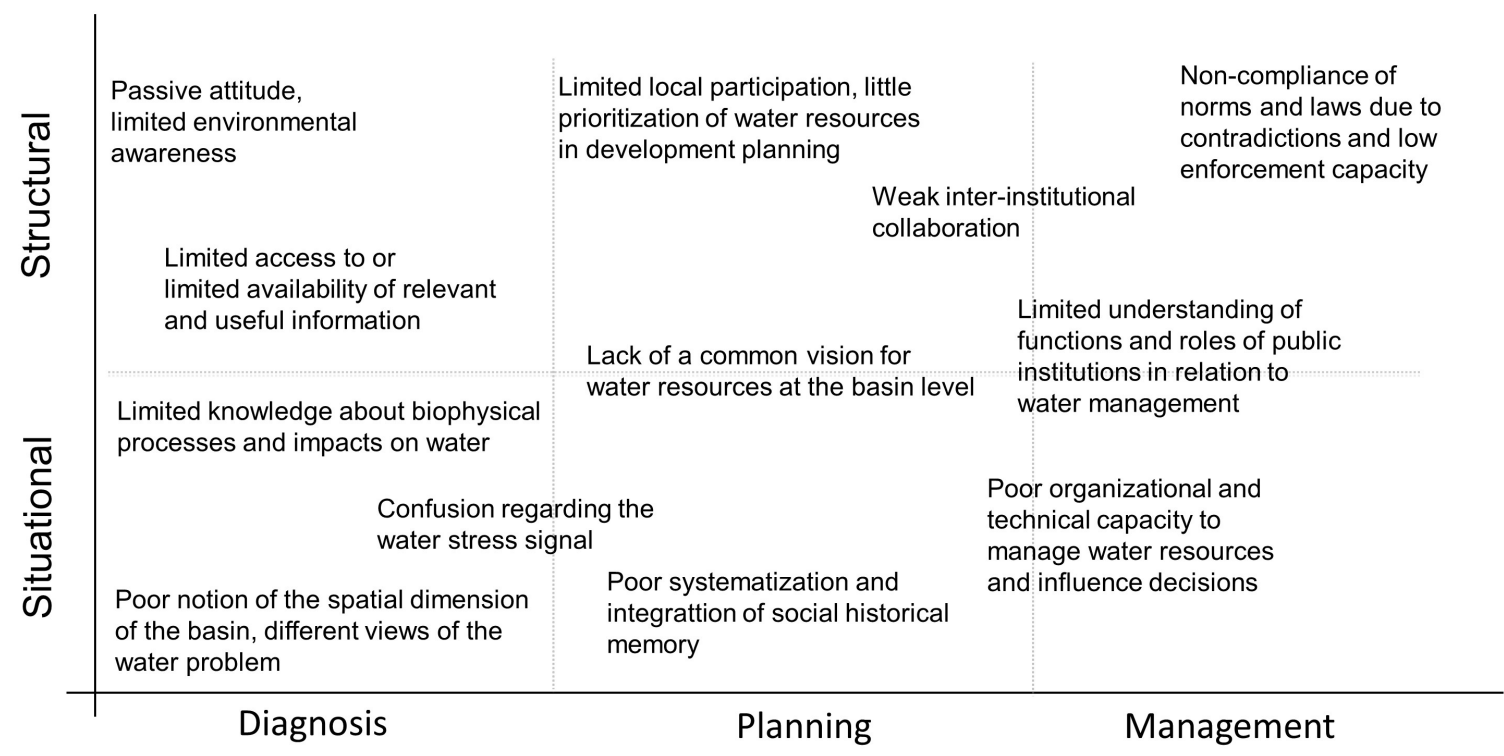

government. These projects tended to focus mainly on infrastructure, and hence, organizational and technical capacity for local water management was lagging. In the JMF, political and power dynamics hindered local participation. Also, many interviewees in the JMF mentioned fatigue around dialogue processes that had led to little impact or no practical action. In the AAMMF, the planning process was more centralized, with only a few spaces for public dialogue and consultation emerging in recent years.

\section{Barriers in the management phase}

Many barriers limited water resources management. A principal common factor was the weak interinstitutional collaboration in the model forests. Among other reasons, interviewees attributed weak collaboration to redundant or at times contradictory mandates in public institutions, little environmental awareness, and a passive attitude toward risk. The loss of credibility and trust in public entities and their capacities to fulfill their mandates also hindered collaboration in the JMF. In the AAMMF, the dependency on top-down decisions coming from the national government seemed to have contributed over time to a hands-off attitude among local actors. This passive attitude seemed to have limited the capacity to anticipate and manage future risk from the bottom-up. In all study sites, poor collaboration was accompanied by weak implementation of the regulatory framework, which was complicated by factors such as insufficient resources and capacity for monitoring and enforcement.

\section{Points of intervention to overcome barriers and enhance adaptation}

Most of the opportunities and points of intervention that could help facilitate adaptation decision making in the study sites helped overcome barriers in the diagnosis and early planning phases (Fig. 4). All the opportunities and interventions built on existing capacity in the model forests.
A possible entry point to generate wider interest on watershed conservation was the general recognition of early warning ecological signals in the three sites, such as forest degradation and soil erosion. These signals suggested possible undesirable outcomes for water resources, such as water contamination and future scarcity. Local perceptions about recent changes in precipitation patterns and the associated effects also contributed to recognizing the need to anticipate future risk.

Equally important, many interviewees called for more interdisciplinary studies that could help bring together the hydrological, ecological, climatic, and land-use change aspects to understand the dynamics between water, forests, and climate in the basins. Capacities to generate such information already exist among local universities and research institutes in the sites, but they were either not employed in a systematic way or the studies were not accessible and ready to use by potential users. Therefore, interviewees indicated that an additional point of intervention could be to translate and reformat this information to make it more user and context specific so that it could be used to inform decisions at the local level.

Another point of intervention common to all sites was the genuine interest for a larger and more inclusive debate about water. Even in the AAMMF, where decisions tended to be more hierarchical and top-down, civil society representatives stated their preparedness to create spaces for dialogue to voice their discontent with the current water legal framework. In the JMF and CMF, participants indicated their interest to invest in awareness-raising campaigns, potentially working with educational centers (primary schools) and the media (in particular, radio and environmental journalists) to initiate a wider debate on water issues and potential management solutions. 
Fig. 4. Categorization of the points of intervention that could help overcome barriers to adaptation decision making for water security in the three model forests. The $\mathrm{x}$-axis organizes the suggested interventions in terms of their relevance to the formal phases of adaptation decision making. The y-axis separates the interventions according to their potential to overcome situational (contemporary) barriers and structural (legacy) barriers.

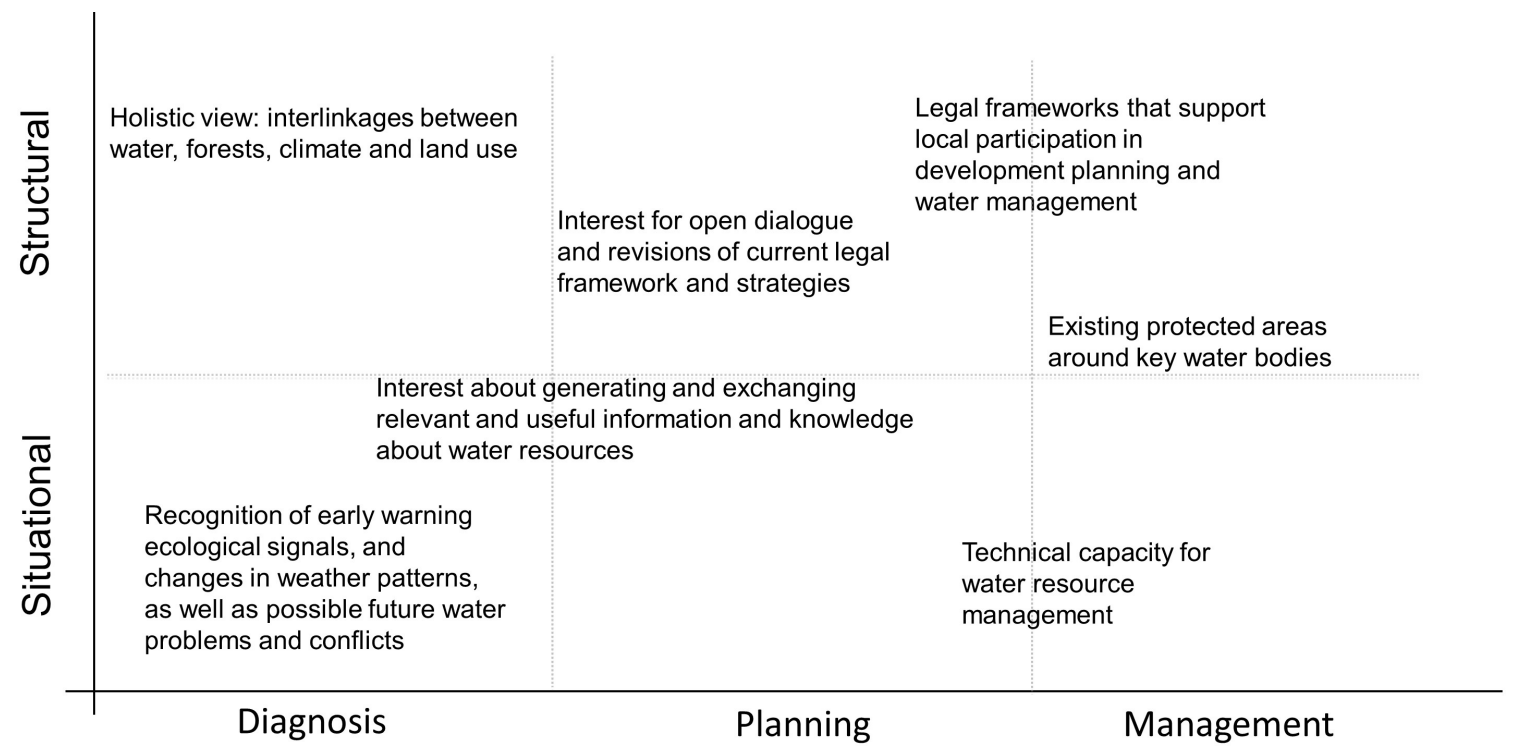

Finally, we found existing regulatory instruments with clear potential to help overcome barriers hindering adaptation planning and management for future water security. For example, the recently introduced Ley de Participación Cuidadana in the AAMMF has the potential to promote more local participation in development planning and adaptation decision making. In the $\mathrm{JMF}$ and CMF, protected areas around the main water dams in the pilot areas were established in the mid-2000s to promote water conservation. These existing legal instruments could be strengthened to implement more integrated water management strategies in these areas.

\section{DISCUSSION}

\section{Local agency in the water governance network}

Our study revealed that municipal governments, and in some instances the model forest boards and CSOs, were considered bridging actors in the water governance networks. This was mentioned several times in the validation workshops. In the network maps, the municipal governments of the CMF and JMF played a central role because they connected multiple actor types with varying views and interests, they linked different governance levels, and they were considered important information brokers. We think that these attributes make these bridging actors potential agents of change that can facilitate collaboration and more inclusive participation in water management and adaptation planning.

Furthermore, workshop participants in the CMF and AAMMF emphasized that the model forest boards and CSOs could play the role of mediators given their experience in generating and sharing information and facilitating a space for dialogue in the landscapes. Despite these assertions, we noticed that in the AAMMF, the CSO SEPADE and the model forest board were not included in the water governance network. Prior to our study, water had not been part of the scope of work and strategy of SEPADE, which probably explains their absence in the network map. In the CMF, the CSO FCBC was identified as a minor actor in the governance network, clustered with a group of other similar CSOs working in the pilot area. This might be explained by their main focus on forest conservation and not water management specifically. Regardless, participants in the AAMMF and CMF perceived that the model forest CSOs and boards could be important mediators should conflicts around water arise in the future.

\section{Overcoming barriers that hinder adaptation planning for future} water security

Most points of intervention focused on overcoming situational barriers in the diagnosis phase and early planning phase of the adaptation decision-making process. These were mainly cognitive barriers linked to (1) incomplete understanding of the biophysical characteristics and dynamics in water basins, (2) confusion about the role and responsibility of different organizations for water governance, (3) limited knowledge about the state of water resources and the environment in general, (4) weak connection to sources of information and poor access to information that is useful to inform decisions, and (5) fragmented and diverging perspectives on the water problem and lack of a common vision for water management and associated risks.

In line with Moser and Ekstrom (2010), we found that some barriers to adaptation planning could be overcome with concerted effort, creative management, and changes in thinking. The points of intervention that were common to the three sites related mainly to facilitating empowerment and local participation in the process of knowledge coproduction and decision making. This involves strengthening existing participatory processes to influence 
decision making, building connections with the research and education sector, and creating spaces for dialogue and exchange to produce information that is more useful and relevant for decision making. It also entails strengthening the role of bridging actors that are considered information brokers in the water governance networks so that they can become more proactive at facilitating cross-domain dialogue and work.

It was more difficult to find sensible points of intervention to overcome structural barriers, which affected the later phases of adaptation planning and management. This is not surprising given that these barriers were created over longer periods of time (Moser and Ekstrom 2010) and were more institutional and normative in nature (Jones and Boyd 2011). However, we argue that addressing barriers in the diagnosis phase is very valuable and indeed critical because this phase will inevitably shape the intentional, planned adaptation process that follows. Moreover, points of intervention that improve the diagnosis of the problem and foster collaboration in early planning can be considered a noregret strategy, with few perceived trade-offs, even under a range of different possible climatic conditions related to both increased climate variability and change over the long term (Hallegatte 2009, Moss et al. 2013, Klein et al. 2014, Preston et al. 2015).

In fact, the involvement of model forest CSOs and local actors in our study has already started to tackle barriers in the diagnosis phase. Working jointly with these actors has proved to be a successful way to raise awareness about water issues in the model forests and to create genuine interest in moving forward to plan for adaptation. Particularly, the involvement of model forest CSOs in the development and implementation of the research had significant implications because it raised questions not only about technological, economic, and political aspects of water, but also about better organizational mechanisms and processes through which diverse actors can come together to inform and influence planning decisions. In this process of coconstruction, we also learned many lessons, some of which we share next.

\section{Lessons learned in the process of coconstruction}

From the beginning, this research was conducted through constant exchange between the team of scientists, the model forest CSOs, and a range of local actors in the sites, including farmers, entrepreneurs, and policy makers. This process of coconstruction proved positive in many different ways, but particularly because it helped (1) to generate interest about water and climate change among the general public, (2) to coproduce information that is more relevant and ready to use in planning decisions, (3) to facilitate legitimacy and appropriation of the outputs, and (4) to empower the participants to become potential agents of change in their localities (Prins et al. 2015). These outcomes confirmed propositions by Moss et al. (2013) and Young et al. (2014) stating that framing the research problem and questions jointly with the potential users of that research can generate more useful, actionable findings and help close the information usability gap.

Certainly, this joint work at the science-society interface also allowed the integration of different forms of knowledge. Leach et al. (2010) emphasized that such spaces for integration and recognition of diverse perspectives have the potential to address power issues in knowledge production and decision making, where technical and scientific knowledge tend to dominate over more traditional forms of knowledge. In our study, different forms of knowledge were recognized, and the focus was on finding ways to integrate them. Similar to Young et al. (2014), the work across knowledge domains helped move toward more transdisciplinary research and hence helped generate a more comprehensive understanding of the problems around water resources in the sites.

In line with action-research studies (Lemos et al. 2012, Groot et al. 2014, Waylen and Young 2014), the process of coconstruction we adopted proved to build greater collective understanding of the study problem, break silo thinking, and increase interest among diverse actors in participating in decision making. However, like Sarkki et al. (2013), we found that in practice, there were also many trade-offs when working at the science-society interface. An important trade-off we faced was between producing relevant and usable information in the policy and practice domains and the quality of that information in the scientific domain (Leclerc et al. 2014). In the process, we also learned that it was necessary to keep a high level of adaptability and communication to be as inclusive, flexible, and realistic as possible about the different expectations, limitations, and uncertainties of the study.

Limitations of the study relate first to the subjectivity associated with the perceptions of the multiple actors involved in the process. We acknowledge that selection of participants relied heavily on the work experience of model forest CSOs in the sites. This could have generated a bias. The study could therefore be complemented with the perceptions of more participants, particularly more participants from the private sector that were difficult to reach at times, e.g., large hydroelectric companies and agricultural associations. Despite this challenge, we managed to engage actors from different sectors. In addition, the participatory approach we adopted enabled the involvement of actors such as farmers, indigenous communities, and citizens, whose concerns are usually more "hidden" in studies in which techno-scientific forms of knowledge dominate.

Another limitation is that the network mapping generated a comprehensive but static picture of the current actors and their interactions for water governance in the model forests. However, at the time of our study, political and social dynamics were strongly affecting the water governance networks, particularly in the JMF. This complicated the network mapping exercise because actors and their relationships were rapidly changing, bringing uncertainty about the future structure and function of the networks. To a large extent, we were able to manage this uncertainty by combining network analysis with the semistructured interviews and workshops, both of which gave us insights about the dynamics influencing water governance and ultimately adaptation decision making. Constant communication between the local CSOs and the team of scientists was also essential to capture these local changing conditions in the results.

\section{CONCLUSION}

Our study demonstrates that coordinated effort among different actor types working in multidomain groups has the potential to enhance local adaptive capacity and create genuine interest in further knowledge coproduction at the science-society interface. The findings also show that studying social and institutional factors that affect water governance and adaptation decision making is an appropriate way to find concrete interventions that 
can generate a more comprehensive understanding of the problem and improve anticipation and adaptation planning for future water security. This approach is relevant and easily replicable in other multiactor forest landscapes worldwide.

Finally, considerably more effort is needed to strengthen the engagement that brings together the scientific community and the civil society using an action-research framework. This work should involve civil society in coleading, framing, and driving the process, but also integrate innovative ways to reduce the potential trade-offs limiting the outcomes.

Responses to this article can be read online at: http://www.ecologyandsociety.org/issues/responses. $\mathrm{php} / 8988$

\section{Acknowledgments:}

This study was conducted as part of the EcoAdapt project "Ecosystem-based Strategies and Innovations in Water Governance Networks for Adaptation to Climate Change in Latin American Landscapes." EcoAdapt is a four-year action-research project funded under the EU Framework Programme (ENV.2011.4.2.3-1 ENV). Project information can be found at http://www.ecoadapt. eul. We thank the coordinators and teams of field researchers and assistants in Bolivia, Chile, and Argentina that collaborated with the data collection and provided critical support and feedback for this study. We also thank the anonymous reviewers that helped greatly to improve the manuscript.

\section{LITERATURE CITED}

Alcamo, J., M. Flörke, and M. Märker. 2007. Future long-term changes in global water resources driven by socio-economic and climatic changes. Hydrological Sciences Journal 52(2):247-275. http://dx.doi.org/10.1623/hysj.52.2.247

Andrew, C., and M. Goldsmith. 1998. From local government to local governance - and beyond? International Political Science Review 19(2):101-117. http://dx.doi.org/10.1177/019251298019002002

Avelino, F., and J. Rotmans. 2009. Power in transition: an interdisciplinary framework to study power in relation to structural change. European Journal of Social Theory 12 (4):543-569. http://dx.doi.org/10.1177/1368431009349830

Bang, H. P., editor. 2003. Governance as a social and political communication. Manchester University Press, Manchester, UK.

Bodin, Ö., and B. I. Crona. 2009. The role of social networks in natural resource governance: What relational patterns make a difference? Global Environmental Change 19(3):366-374. http:// dx.doi.org/10.1016/j.gloenvcha.2009.05.002

Bolivia. 2010. Bolivia Ley No 031 del 19 Julio 2010: ley marco de autonomías y descentralización "Andrés Ibáñez". Gaceta Oficial de Bolivia, Sucre, Bolivia. [online] URL: http://www.derechoteca. com/gacetabolivia/ley-031-del-19-julio-2010/

Bolivia. 2014. Ley No 482 de Enero de 2014: ley de gobiernos autónomos municipales. Gaceta Oficial de Bolivia, Sucre, Bolivia. [online] URL: http://www.chuquisaca.gob.bo/riesgos/images/ descargas/Ley_GobiernosMunicipales.pdf
Borgatti, S. P. 2002. NetDraw software for network visualization. Analytic Technologies, Lexington, Kentucky, USA. [online] URL: https://sites.google.com/site/netdrawsoftware/home

Borgatti, S. P., M. G. Everett, and L. C. Freeman. 2002. Ucinet for Windows: software for social network analysis. Analytic Technologies, Harvard, Massachusetts, USA. [online] URL: https://sites.google.com/site/ucinetsoftware/home

Bradshaw, G. A., and J. G. Borchers. 2000. Uncertainty as information: narrowing the science-policy gap. Conservation Ecology 4(1):7. http://dx.doi.org/10.5751/es-00174-040107

Carlsson, L., and F. Berkes. 2005. Co-management: concepts and methodological implications. Journal of Environmental Management 75(1):65-76. http://dx.doi.org/10.1016/j.jenvman.2004.11.008

Cash, D. W., W. C. Clark, F. Alcock, N. M. Dickson, N. Eckley, D. H. Guston, J. Jäger, and R. B. Mitchell. 2003. Knowledge systems for sustainable development. Proceedings of the National Academy of Sciences 100(14):8086-8091. http://dx.doi.org/10.1073/ pnas. 1231332100

Crona, B., and Ö. Bodin. 2010. Power asymmetries in small-scale fisheries: a barrier to governance transformability? Ecology and Society 15(4):32. [online] URL: http://www.ecologyandsociety. org/vol15/iss4/art32/

Crona, B., and K. Hubacek. 2010. The right connections: How do social networks lubricate the machinery of natural resource governance? Ecology and Society 15(4):18. [online] URL: http:// www.ecologyandsociety.org/vol15/iss4/art18/

Döll, P. 2009. Vulnerability to the impact of climate change on renewable groundwater resources: a global-scale assessment. Environmental Research Letters 4(3):035006. http://dx.doi. org/10.1088/1748-9326/4/3/035006

Elbakidze, M., P. K. Angelstam, C. Sandström, and R. Axelsson. 2010. Multi-stakeholder collaboration in Russian and Swedish Model Forest initiatives: adaptive governance toward sustainable forest management? Ecology and Society 15(2):14. http://dx.doi. org/10.5751/es-03334-150214

Groot, A., K. Hollaender, and R. Swart. 2014. Productive sciencepractice interactions in climate change adaptation: lessons from practice. CIRCLE-2 Research Policy Brief. Foundation of the Faculty of Sciences, Lisbon, Portugal. [online] URL: http://www. circle-era.eu/np4/\%7B SclientServletPath $\% 7 \mathrm{D} /$ ?newsId=674\&fileName= CIRCLE2 ProductiveSciencePracticeInterac.pdf

Hallegatte, S. 2009. Strategies to adapt to an uncertain climate change. Global Environmental Change 19(2):240-247. http://dx. doi.org/10.1016/j.gloenvcha.2008.12.003

Hanneman, R. A., and M. Riddle. 2005. Introduction to social network methods. University of California, Riverside, California, USA. [online] URL: http://faculty.ucr.edu/ hanneman/

Hantke Domas, M. 2011. Avances legislativos en gestión sostenible $y$ descentralizada del agua en América Latina. Economic Commission for Latin America and the Caribbean, Santiago de Chile, Chile. [online] URL: http://www.cepal.org/es/publicaciones/3942avances-legislativos-gestion-sostenible-descentralizada-agua-americalatina 
Hooghe, L., and G. Marks. 2003. Unraveling the central State, but how? Types of multi-level governance. American Political Science Review 97(2):233-243. [online] URL: http://www.jstor. org/stable/3118206

International Model Forest Network (IMFN). 2011. The International Model Forest Network: a global approach to ecosystem sustainability. IMFN, Ottawa, Canada. [online] URL: http://www.imfn.net/userfiles/IMFN Book Eng web.pdf

Jiménez Cisneros, B. E., T. Oki, N. W. Arnell, G. Benito, J. G. Cogley, P. Döll, T. Jiang, and S. S. Mwakalila. 2014. Freshwater resources. Pages 229-269 in C. B. Field, V. R. Barros, D. J. Dokken, K. J. Mach, M. D. Mastrandrea, T. E. Bilir, M. Chatterjee, K. L. Ebi, Y. O. Estrada, R. C. Genova, B. Girma, E. S. Kissel, A. N. Levy, S. MacCracken, P. R. Mastrandrea, and L. L. White, editors. Climate change 2014: impacts, adaptation, and vulnerability. Part A: global and sectoral aspects. Contribution of Working Group II to the Fifth Assessment Report of the Intergovernmental Panel on Climate Change. Cambridge University Press, Cambridge, UK. [online] URL: http://ipcc-wg2.gov/AR5/images/uploads/ WGIIAR5-Chap3 FINAL.pdf

Jones, L., and E. Boyd. 2011. Exploring social barriers to adaptation: insights from western Nepal. Global Environmental Change 21(4):1262-1274. http://dx.doi.org/10.1016/j.

gloenvcha.2011.06.002

Klein, R. J. T., G. F. Midgley, B. L. Preston, M. Alam, F. G. H. Berkhout, K. Dow, and M. R. Shaw. 2014. Adaptation opportunities, constraints, and limits. Pages 899-943 in C. B. Field, V. R. Barros, D. J. Dokken, K. J. Mach, M. D. Mastrandrea, T. E. Bilir, M. Chatterjee, K. L. Ebi, Y. O. Estrada, R. C. Genova, B. Girma, E. S. Kissel, A. N. Levy, S. MacCracken, P. R. Mastrandrea, and L. L. White, editors. Climate change 2014: impacts, adaptation, and vulnerability. Part A: global and sectoral aspects. Contribution of Working Group II to the Fifth Assessment Report of the Intergovernmental Panel on Climate Change. Cambridge University Press, Cambridge, UK. [online] URL: http://ipcc-wg2.gov/AR5/images/uploads/WGIIAR5Chap16 FINAL.pdf

Klijn, E.-H. 2008. Governance and governance networks in Europe. Public Management Review 10(4):505-525. http://dx.doi. org/10.1080/14719030802263954

Leach, M., I. Scoones, and A. Stirling. 2010. Dynamic sustainabilities: technology, environment, social justice. Earthscan, London, UK.

Leclerc, G., M. Coll Besa, T. Devisscher, A. Fallot, F. Jankowski, J.-F. Le Coq, V. Raffaele, M. Morales, and C. Prins. 2014. EcoAdapt: adaptation to climate change for local development in model forests of Argentina, Bolivia and Chile: trade-offs for supporting robust local processes at the science-society interface. Pages 717-718 in Resilience and development: mobilising for transformation. Resilience Alliance Network: CIRAD-CNRSIRSTEA-INRA, Montpellier, France. [online] URL: https:// drive.google.com/file/d/0B3CTvjSxBMlMdGRiWDRRX3pHWkk/ edit?usp=sharing

Lemos, M. C., C. J. Kirchhoff, and V. Ramprasad. 2012. Narrowing the climate information usability gap. Nature Climate Change 2:789-794. http://dx.doi.org/10.1038/nclimate1614
Magrin, G. O., J. A. Marengo, J.-P. Boulanger, M. S. Buckeridge, E. Castellanos, G. Poveda, F. R. Scarano, and S. Vicuña. 2014. Central and South America. Pages 1499-1566 in C. B. Field, V. R. Barros, D. J. Dokken, K. J. Mach, M. D. Mastrandrea, T. E. Bilir, M. Chatterjee, K. L. Ebi, Y. O. Estrada, R. C. Genova, B. Girma, E. S. Kissel, A. N. Levy, S. MacCracken, P. R. Mastrandrea, and L. L. White, editors. Climate change 2014: impacts, adaptation, and vulnerability. Part A: global and sectoral aspects. Contribution of Working Group II to the Fifth Assessment Report of the Intergovernmental Panel on Climate Change. Cambridge University Press, Cambridge, UK. [online] URL: http://ipcc-wg2.gov/AR5/images/uploads/WGIIAR5Chap27 FINAL.pdf

Moser, S. C., and J. A. Ekstrom. 2010. A framework to diagnose barriers to climate change adaptation. Proceedings of the National Academy of Sciences 107(51):22026-22031. http://dx.doi. org/10.1073/pnas.1007887107

Moss, R. H., G. A. Meehl, M. C. Lemos, J. B. Smith, J. R. Arnold, J. C. Arnott, D. Behar, G. P. Brasseur, S. B. Broomell, A. J. Busalacchi, S. Dessai, K. L. Ebi, J. A. Edmonds, J. Furlow, L. Goddard, H. C. Hartmann, J. W. Hurrell, J. W. Katzenberger, D. M. Liverman, P. W. Mote, S. C. Moser, A. Kumar, R. S. Pulwarty, E. A. Seyller, B. L. Turner II, W. M. Washington, and T. J. Wilbanks. 2013. Hell and high water: practice-relevant adaptation science. Science 342:696-698. http://dx.doi.org/10.1126/science.1239569

Newig, J., D. Günther, and C. Pahl-Wostl. 2010. Synapses in the network: learning in governance networks in the context of environmental management. Ecology and Society 15(4):24. [online] URL: http://www.ecologyandsociety.org/vol15/iss4/ $\underline{\operatorname{art} 24 /}$

Nutley, S. M., I. Walter, and H. T. O. Davies. 2007. Using evidence: how research can inform public services. Policy Press, Bristol, UK.

Olsson, P., C. Folke, and F. Berkes. 2004. Adaptive comanagement for building resilience in social-ecological systems. Environmental Management 34(1):75-90. http://dx.doi.org/10.1007/s00267-003-0101-7

Ostrom, E. 2005. Understanding institutional diversity. Princeton University Press, Princeton, New Jersey, USA.

Pelling, M., C. High, J. Dearing, and D. Smith. 2008. Shadow spaces for social learning: a relational understanding of adaptive capacity to climate change within organisations. Environment and Planning A 40(4):867-884. http://dx.doi.org/10.1068/a39148

Pielke, R. A. Jr. 2007. The honest broker: making sense of science in policy and politics. Cambridge University Press, Cambridge, UK. http://dx.doi.org/10.1017/cbo9780511818110

Preston, B. L., J. Mustelin, and M. C. Maloney. 2015. Climate adaptation heuristics and the science/policy divide. Mitigation and Adaptation Strategies for Global Change 20:467-497. http://dx. doi.org/10.1007/s11027-013-9503-X

Prins, K., A. C. Cattán, N. Azcarrúnz, A. Real, L. Villagron, G. Leclerc, R. Vignola, M. Morales, and B. Louman. 2015. Creating and sharing new knowledge through joint learning on water governance and climate change adaptation in three Latin American Model Forests: the EcoAdapt case. IUFRO Occasional Paper 30. International Union of Forest Research Organizations, Wien, Austria. [online] URL: http://www.iufro.org/publications/series/ 
occasional-papers/article/2015/12/17/iufro-occasional-paper-30-creatingand-sharing-new-knowledge-through-joint-learning-on-water-gover-1/

Rhodes, R. A. W. 1996. The new governance: governing without government. Political studies 44(4):652-667. http://dx.doi. org/10.1111/j.1467-9248.1996.tb01747.x

Sandström, A., and C. Rova. 2010. Adaptive co-management networks: a comparative analysis of two fishery conservation areas in Sweden. Ecology and Society 15(3):14. [online] URL: http://www.ecologyandsociety.org/vol15/iss3/art14/

Sarkki, S., J. Niemelä, R. Tinch, S. van den Hove, A. Watt, and J. Young. 2013. Balancing credibility, relevance and legitimacy: a critical assessment of trade-offs in science-policy interfaces. Science and Public Policy 41(2):194-206. http://dx.doi. org/10.1093/scipol/sct046

Schiffer, E. 2007. Manual: Net-Map toolbox: influence mapping of social networks. International Food Policy Research Institute, Washington, D.C., USA. [online] URL: https://netmap.files. wordpress.com/2007/11/net-map-manual-final.doc

Schiffer, E., and J. Hauck. 2010. Net-Map: collecting social network data and facilitating network learning through participatory influence network mapping. Field Methods 22 (3):231-249. http://dx.doi.org/10.1177/1525822x10374798

Shiklomanov, I. A., and J. C. Rodda, editors. 2003. World water resources at the beginning of the 21 st century. Cambridge University Press, Cambridge, UK.

Smith, A., A. Stirling, and F. Berkhout. 2005. The governance of sustainable socio-technical transitions. Research Policy 34 (10):1491-1510. http://dx.doi.org/10.1016/j.respol.2005.07.005

Stein, C., H. Ernstson, and J. Barron. 2011. A social network approach to analyzing water governance: the case of the Mkindo catchment, Tanzania. Physics and Chemistry of the Earth, Parts A/B/C 36(14-15):1085-1092. http://dx.doi.org/10.1016/j.pce.2011.07.083

Tortajada, C. 1999. River basins: institutional framework and management options for Latin America. Working Paper of the World Commission on Dams. World Commission on Dams, Cape Town, South Africa.

Van den Hove, S. 2006. Between consensus and compromise: acknowledging the negotiation dimension in participatory approaches. Land Use Policy 23(1):10-17. http://dx.doi. org/10.1016/j.landusepol.2004.09.001

Van den Hove, S. 2007. A rationale for science-policy interfaces. Futures 39(7):807-826. http://dx.doi.org/10.1016/j.futures.2006.12.004

Vignola, R., T. L. McDaniels, and R. W. Scholz. 2013. Governance structures for ecosystem-based adaptation: using policy-network analysis to identify key organizations for bridging information across scales and policy areas. Environmental Science and Policy 31:71-84. http://dx.doi.org/10.1016/j.envsci.2013.03.004

Vogel, C., S. C. Moser, R. E. Kasperson, and G. D. Dabelko. 2007. Linking vulnerability, adaptation, and resilience science to practice: pathways, players, and partnerships. Global Environmental Change 17(3-4):349-364. http://dx.doi.org/10.1016/ j.gloenvcha.2007.05.002
Vörösmarty, C. J., P. Green, J. Salisbury, and R. B. Lammers. 2000. Global water resources: vulnerability from climate change and population growth. Science 289:284-288. http://dx.doi.org/10.1126/ science.289.5477.284

Waylen, K. A, and J. Young. 2014. Expectations and experiences of diverse forms of knowledge use: the case of the UK National Ecosystem Assessment. Environment and Planning C: Government and Policy 32(2):229-246. http://dx.doi.org/10.1068/c1327j

Young, J. C., A. D. Watt, and S. van den Hove. 2013. Effective interfaces between science, policy and society: the SPIRAL project handbook. Spiral, Europe. [online] URL: http://www.spiralproject.eu/sites/default/files/The-SPIRAL-handbook-website.pdf

Young, J. C., K. A. Waylen, S. Sarkki, S. Albon, I. Bainbridge, E. Balian, J. Davidson, D. Edwards, R. Fairley, C. Margerison, D. McCracken, R. Owen, C. P. Quine, C. Stewart-Roper, D. Thompson, R. Tinch, S. van den Hove, and A. Watt. 2014. Improving the science-policy dialogue to meet the challenges of biodiversity conservation: having conversations rather than talking at one-another. Biodiversity and Conservation 23 (2):387-404. http://dx.doi.org/10.1007/s10531-013-0607-0 


\section{Appendix 1. List of the Working Papers linked to this study.}

\section{EcoAdapt Working Paper Series $N^{\circ} 12$}

Climate change and water: Analysis of the socio-institutional context in the Perico-Manantiales watershed, Argentina. (Only available in Spanish). Available at: https://docs.google.com/viewer?a=v\&pid=sites\&srcid=ZGVmYXVsdGRvbWFpbnxIY29hZGFwdHBy b2plY3RIbmdsaXNofGd4OjZmNDk1Yjc4MzNkMjY4YjQ

EcoAdapt Working Paper Series $N^{\circ} 16$

Climate change and water: Analysis of the socio-institutional context in Lonquimay and Curacautin, Chile. (Only available in Spanish). Available at:

https://docs.google.com/viewer?a=v\&pid=sites\&srcid=ZGVmYXVsdGRvbWFpbnxlY29hZGFwdHBy b2plY3RIbmdsaXNofGd4OjQzNWY4ZGUyMTUyMTNjMmU

EcoAdapt Working Paper Series $N^{\circ} 18$

Climate change and water: Analysis of the socio-institutional context in Chiquitano Model Forest, Bolivia. (Only available in Spanish). Available at:

https://docs.google.com/viewer?a=v\&pid=sites\&srcid=ZGVmYXVsdGRvbWFpbnxlY29hZGFwdHBy b2plY3RIbmdsaXNofGd4OjE5NmNkOTNjYTVIM2M4NTM 
Appendix 2. Water governance networks in the Jujuy Model Forest and the Araucarias del Alto Malleco Model Forest.

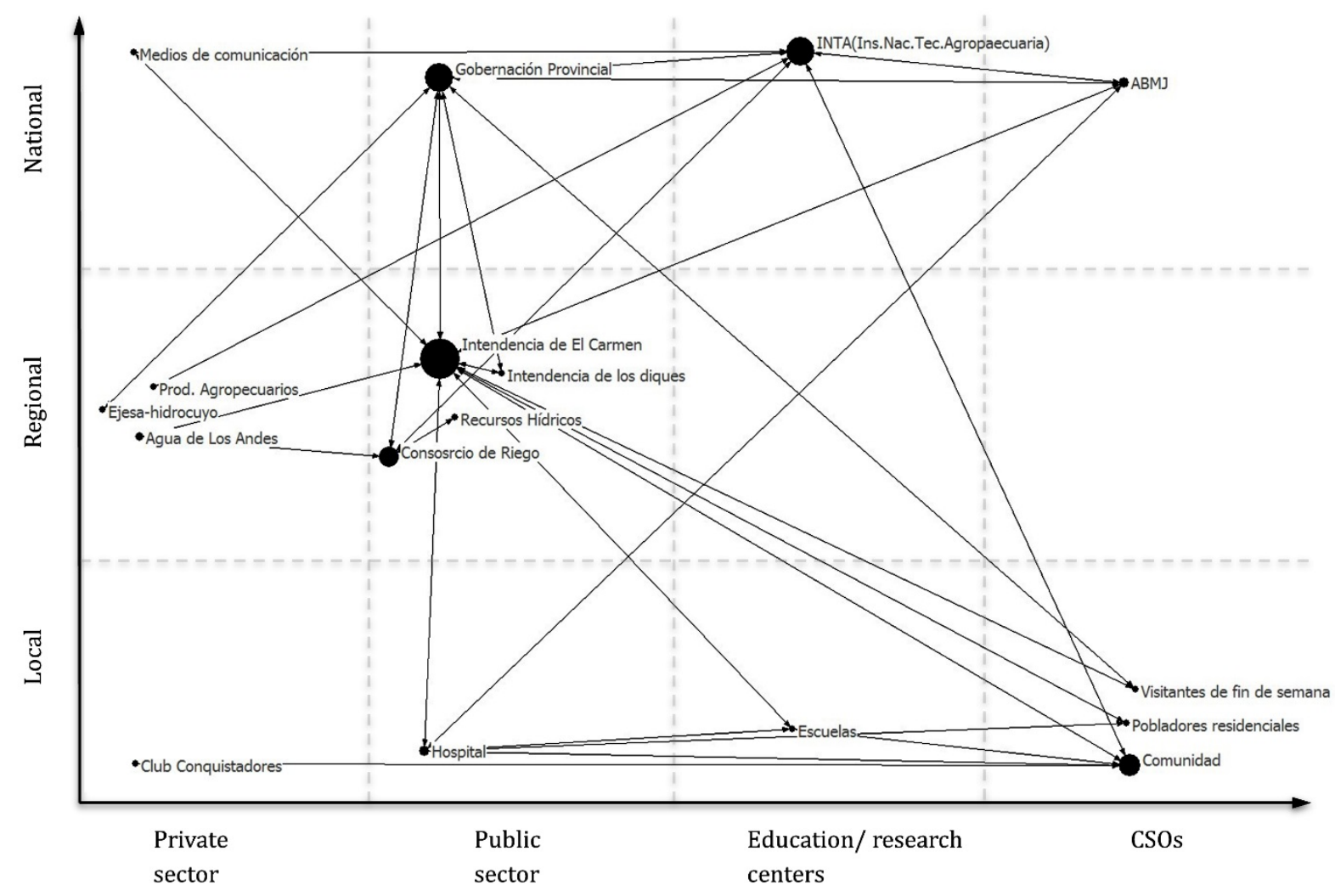

Fig. A2.1. Water governance network from the perspective of representatives of local public entities in the Jujuy Model Forest (JMF), Argentina. The actor nodes in the networks represent organizations and social groups perceived as relevant to water resources management. The $\mathrm{x}$-axis categorizes the actor nodes according to the sector they relate to. Civil society organizations (CSOs) include nongovernmental organizations. The $y$-axis categorizes actor nodes by their scale of action. The local scale relates to the pilot area in the JMF, the regional scale corresponds to the model forest landscape, and the national scale represents Argentina. Actor node size relates to inbetweenness centrality, which corresponds to the importance of the node as bridge in the network. See Appendix 3 for a list of the main actors and the role they play in the water governance network according to participants' perception. 


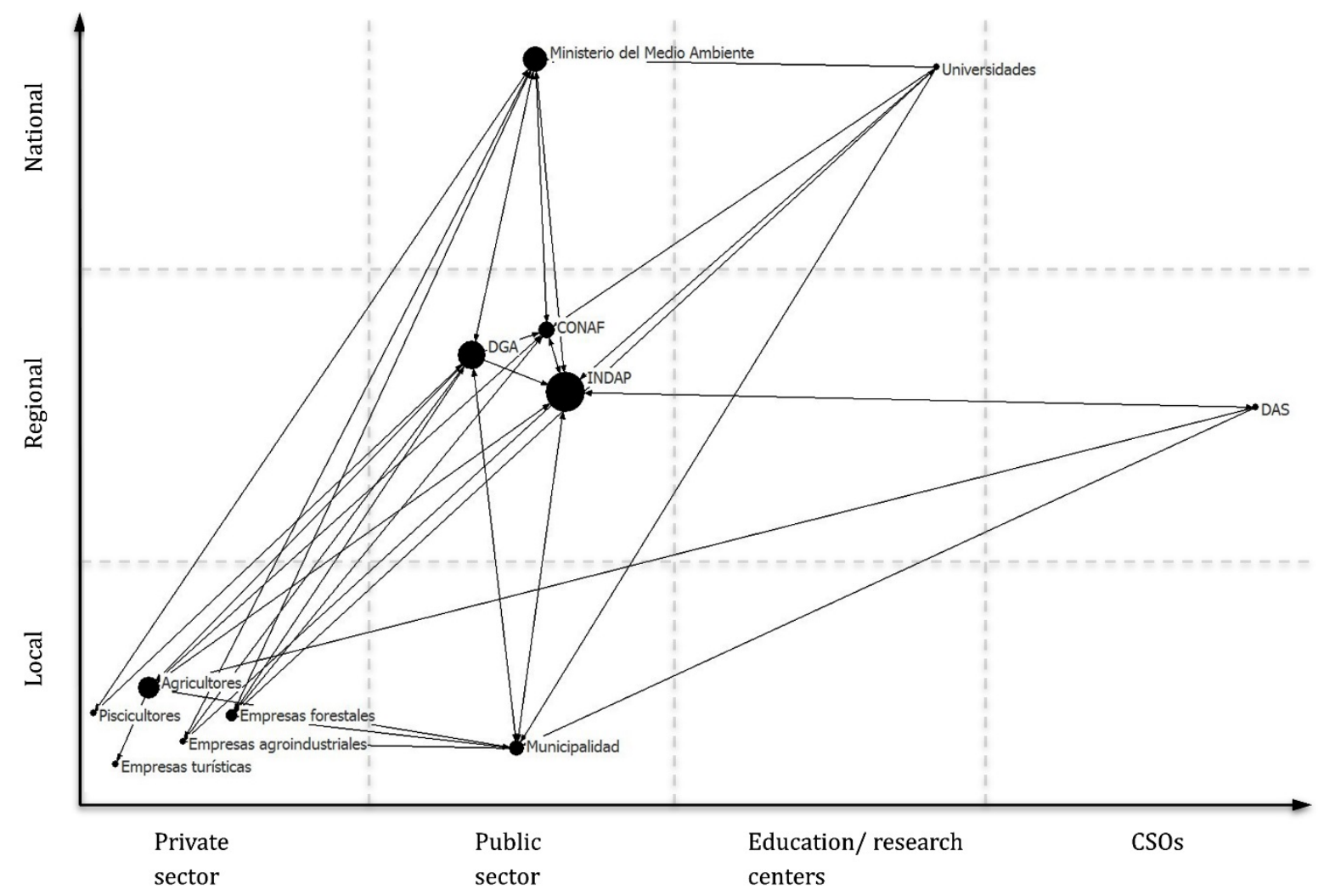

Fig. A2.2. Water governance network from the perspective of representatives of public entities in the Araucarias del Alto Malleco Model Forest (AAMMF), Chile. The actor nodes in the networks represent organizations and social groups perceived as relevant to water resources management. The $\mathrm{x}$-axis categorizes the actor nodes according to the sector they relate to. Civil society organizations (CSOs) include non-governmental organizations. The $y$-axis categorizes actor nodes by their scale of action. The local scale relates to the pilot area in the AAMMF, the regional scale corresponds to the model forest landscape, and the national scale represents Chile. Actor node size relates to inbetweenness centrality, which corresponds to the importance of the node as bridge in the network. See Appendix 3 for a list of the main actors and the role they play in the water governance network according to participants' perception. 
Appendix 3. Main actors in the water governance networks and their roles according to participants' perception.

Table A3.1. Main actors and perceived roles in the water governance network of the Jujuy Model Forest

\begin{tabular}{|c|c|c|}
\hline ACTOR & SECTOR & ROLE \\
\hline $\begin{array}{l}\text { Agua de Los } \\
\text { Andes }\end{array}$ & Private & $\begin{array}{l}\text { Company responsible for the treatment of drinking water in the } \\
\text { province of Jujuy. It is managed by the provincial government with } \\
\text { public funds. }\end{array}$ \\
\hline $\begin{array}{l}\text { Model Forest } \\
\text { Jujuy (ABMJ) }\end{array}$ & $\begin{array}{l}\text { Civil society } \\
\text { organization }\end{array}$ & $\begin{array}{l}\text { Civil Society Organization that performs actions and executes } \\
\text { projects with the purpose of contributing to an integrated } \\
\text { management of natural resources in Los Pericos - Manantiales } \\
\text { basin, Province of Jujuy. }\end{array}$ \\
\hline $\begin{array}{l}\text { Club } \\
\text { Conquistadores }\end{array}$ & Private & $\begin{array}{l}\text { Private organisations that organize leisure activities in the ADP } \\
\text { area (e.g. recreational fishing, nautical activities, etc.) }\end{array}$ \\
\hline $\begin{array}{l}\text { Consorcio de } \\
\text { Riego }\end{array}$ & Public & $\begin{array}{l}\text { Water user organization that is part of the private sector. It is } \\
\text { mainly represented by the tobacco producers, which account for } \\
\text { the } 80 \% \text { of the water users. The entity is responsible for the water } \\
\text { distribution in the middle basin. }\end{array}$ \\
\hline Ejesa-Hidrocuyo & Private & $\begin{array}{l}\text { Private company in charge of the production of hydroelectric } \\
\text { power generation. Hidrocuyo is located in the 'Las Maderas' dam } \\
\text { area. }\end{array}$ \\
\hline Schools & $\begin{array}{l}\text { Education } \\
\text { centre }\end{array}$ & $\begin{array}{l}\text { Public education institute in charge of primary, secondary and } \\
\text { tertiary education. }\end{array}$ \\
\hline $\begin{array}{l}\text { Provincial } \\
\text { government }\end{array}$ & Public & $\begin{array}{l}\text { Public administrative entity coordinating with Ministries or } \\
\text { Secretariats. }\end{array}$ \\
\hline Hospital & Public & $\begin{array}{l}\text { Hospital providing medical and surgical treatment and nursing care } \\
\text { for sick or injured people. }\end{array}$ \\
\hline $\begin{array}{l}\text { Instituto } \\
\text { Nacional } \\
\text { Tecnologico } \\
\text { Agropecuario } \\
\text { (INTA) }\end{array}$ & $\begin{array}{l}\text { Research } \\
\text { centre }\end{array}$ & $\begin{array}{l}\text { National institute of that undertakes research on agriculture and } \\
\text { livestock at the national level. }\end{array}$ \\
\hline $\begin{array}{l}\text { Intendencia de } \\
\text { los Diques }\end{array}$ & Public & $\begin{array}{l}\text { Provincial body dependent on the Environmental Management } \\
\text { Secretariat. It is responsible for the management of the Area de los } \\
\text { diques y perilagos (Area of the dams and its surroundings). }\end{array}$ \\
\hline
\end{tabular}




\begin{tabular}{|l|l|l|}
\hline $\begin{array}{l}\text { Intendencia de } \\
\text { El Carmen }\end{array}$ & Public & $\begin{array}{l}\text { Municipal government with both the legislative and executive } \\
\text { mandate and administration of the Municipality El Carmen. }\end{array}$ \\
\hline Local media & Private & $\begin{array}{l}\text { Private communication companies that include TV, radio, and } \\
\text { digital media. Some of them with strong linkages to politicians at } \\
\text { the Provincial level. }\end{array}$ \\
\hline $\begin{array}{l}\text { Rural } \\
\text { communities }\end{array}$ & Civil society & $\begin{array}{l}\text { Communities that live in the area surrounding the water dams and } \\
\text { that use it. In some places, communities have self-organized to form } \\
\text { neighbourhood groups or committees. }\end{array}$ \\
\hline $\begin{array}{l}\text { Residential } \\
\text { communities }\end{array}$ & Civil society & $\begin{array}{l}\text { Middle-high class inhabitants that have weekend houses in the } \\
\text { residential parts of the Area de los diques y perilagos. }\end{array}$ \\
\hline $\begin{array}{l}\text { Agricultural } \\
\text { producers }\end{array}$ & Private & $\begin{array}{l}\text { Water users associated to the Consorcio de Riego, mostly from the } \\
\text { tobacco sector. }\end{array}$ \\
\hline Recursos Hídricos & Public & $\begin{array}{l}\text { Provincial public entity in charge of managing the freshwater and } \\
\text { groundwater. }\end{array}$ \\
\hline Weekend visitors & Civil society & $\begin{array}{l}\text { Local tourists visiting the Area de los diques y perilagos over the } \\
\text { weekend for recreational purpose. }\end{array}$ \\
\hline
\end{tabular}

Table A3.2. Main actors and perceived roles in the water governance network of the Araucarias del Alto Malleco Model Forest

\begin{tabular}{|l|l|l|}
\hline \multicolumn{1}{|c|}{ ACTOR } & \multicolumn{1}{|c|}{ SECTOR } & \multicolumn{1}{c|}{ ROLE } \\
\hline $\begin{array}{l}\text { Dirección } \\
\text { General de } \\
\text { Aguas (DGA) }\end{array}$ & Public & $\begin{array}{l}\text { It provides water use rights. It implements drinking water } \\
\text { projects, water monitoring measurements, etc. }\end{array}$ \\
\hline $\begin{array}{l}\text { Municipalidad } \\
\text { (Lonquimay and } \\
\text { Curacautín) }\end{array}$ & Public & $\begin{array}{l}\text { Linked to water committees and rural drinking water projects. } \\
\text { Some actors attribute the role of the Municipal governments to } \\
\text { issues particularly related to irrigation projects. They have a } \\
\text { general role in facilitating information and consultation. }\end{array}$ \\
\hline $\begin{array}{l}\text { Instituto } \\
\text { Nacional de } \\
\text { Desarrollo } \\
\text { Agropecuario } \\
\text { (INDAP) }\end{array}$ & Public & $\begin{array}{l}\text { Public entity in charge of allocating resources for irrigation } \\
\text { projects and regularization of water use. }\end{array}$ \\
\hline $\begin{array}{l}\text { Corporación } \\
\text { Nacional } \\
\text { Forestal } \\
\text { (CONAF) }\end{array}$ & Public & $\begin{array}{l}\text { Public entity in charge of enforcing forest policies. Focused on the } \\
\text { protection of natural resources, especially forests. }\end{array}$ \\
\hline
\end{tabular}




\begin{tabular}{|l|l|l|}
\hline $\begin{array}{l}\text { Environment } \\
\text { Ministry }\end{array}$ & Public & $\begin{array}{l}\text { Public entity in charge of the assessment of environmental } \\
\text { impacts of projects. It is perceived as an institution that is far } \\
\text { away from the area of study, disconnected from Municipalities } \\
\text { and other organizations. }\end{array}$ \\
\hline $\begin{array}{l}\text { Farmers and } \\
\text { agro-industry }\end{array}$ & $\begin{array}{l}\text { Pater users that require water for production. They are active } \\
\text { and can strengthen the links with others to encourage } \\
\text { participation and work in coordinated ways. }\end{array}$ \\
\hline
\end{tabular}

Table A3.3. Main actors and perceived roles in the water governance network of the Chiquitano Model Forest

\begin{tabular}{|l|l|l|}
\hline \multicolumn{1}{|c|}{ ACTOR } & \multicolumn{1}{|c|}{ SECTOR } & \multicolumn{1}{|c|}{ ROLE } \\
\hline $\begin{array}{l}\text { Municipal } \\
\text { government }\end{array}$ & Public & $\begin{array}{l}\text { Public entity in charge of sustainable development in the urban } \\
\text { and rural areas of the Municipality, promotes production, } \\
\text { enforces national and municipal laws and by-laws. }\end{array}$ \\
\hline $\begin{array}{l}\text { Gobernacion y } \\
\text { Subgobernación }\end{array}$ & Public & $\begin{array}{l}\text { Government entity in charge of administering the Province Nuflo } \\
\text { de Chávez. It provides support in relation to management of } \\
\text { natural resources, water basins and protected areas. }\end{array}$ \\
\hline $\begin{array}{l}\text { Central Indígena } \\
\text { Comunidades } \\
\text { de Concepción } \\
\text { (CICC) }\end{array}$ & $\begin{array}{l}\text { Civil society } \\
\text { organization }\end{array}$ & $\begin{array}{l}\text { Indigenous organization focused on improving the living } \\
\text { conditions of indigenous communities across the Chiquitania. It } \\
\text { aims to foster sustainable development, taking into account } \\
\text { natural resources, cultural identity, community participation and } \\
\text { gender equity. }\end{array}$ \\
\hline $\begin{array}{l}\text { Local } \\
\text { communities }\end{array}$ & Civil society & $\begin{array}{l}\text { Communities can self-organize and form Organizaciones } \\
\text { Territoriales de Base (OTBs). The role of the OTBs is described in } \\
\text { the Law of popular participation and the Law of municipalities. } \\
\text { They coordinate with the surveillance committee to supervise } \\
\text { and evaluate impacts of public policies and participatory } \\
\text { processes in relation to the local development plans. }\end{array}$ \\
\hline $\begin{array}{l}\text { Water } \\
\text { International }\end{array}$ & organization \\
Private & $\begin{array}{l}\text { Con-governmental organization that supports human } \\
\text { development projects and production systems for sustainable } \\
\text { management of natural resources. It works in coordination with } \\
\text { the Municipal government. }\end{array}$ \\
\hline $\begin{array}{l}\text { This private cooperative has a central role in managing the } \\
\text { area and the communities Porvenir and Altamira. }\end{array}$ \\
\hline
\end{tabular}




\begin{tabular}{|l|l|l|}
\hline Vicariate & $\begin{array}{l}\text { Civil society } \\
\text { organization }\end{array}$ & $\begin{array}{l}\text { Catholic church organization focused on human development and } \\
\text { support to the production systems and sustainable management } \\
\text { of natural resources in rural communities. }\end{array}$ \\
\hline $\begin{array}{l}\text { Cattle rancher } \\
\text { association } \\
\text { (AGACON) }\end{array}$ & Private & $\begin{array}{l}\text { Non-profit association that provides services to cattle ranchers in } \\
\text { terms of sanitation as well as legislative and administrative issues. } \\
\text { It also supports the livestock trade system. }\end{array}$ \\
\hline $\begin{array}{l}\text { Fundación para } \\
\text { la Conservación } \\
\text { del Bosque } \\
\text { Chiquitano } \\
\text { (FCBC) }\end{array}$ & $\begin{array}{l}\text { Civil society } \\
\text { organization }\end{array}$ & $\begin{array}{l}\text { Non-governmental organization aimed at providing support in } \\
\text { sustainable management of natural resources and land-use } \\
\text { planning. }\end{array}$ \\
\hline $\begin{array}{l}\text { Autoridad de } \\
\text { Bosques y Tierra } \\
\text { (ABT) }\end{array}$ & Public & $\begin{array}{l}\text { Public entity in charge enforcing forest regulation, and providing } \\
\text { support for integrated forest management. It aims at contributing } \\
\text { to socio-economic development. }\end{array}$ \\
\hline
\end{tabular}

